\title{
透析患者の貧血に対する長期蛋白漏出性血液透析（PPHD）の効果
}

\author{
上野幸司渡辺有義青柳秀夫藤田篤 \\ 小藤田敬介草野 英二* 浅 野 泰* \\ 小金井クリニック 自治医科大学透析センター* \\ (平成 1 年 1 月 26 日受付)
}

key words : chronic renal failure, protein permeable hemodialysis, anemia, uremic toxin

〈要旨〉

維持透析患者の賓血に対する protein permeable hemodialysis (PPHD) の効果と炎の機序について検討した。30 例の維持透析患者のうち, 治療抵抗性の貧血や透析アミロイドーシスを合併した 15 例にセルロース膜系蛋白漏出型ダ イアライザーを使用し (PPHD 群), 他の 15 例は通常の非蛋白漏出性セルロース膜（HD 群）による透析を 7 か月間 継続し, 施行前後の各種パラメーターを比較検討した。PPHD 群 15 例中 7 例 (47\%) に貲血の改善を認め, 輸血量も $0.26 \pm 0.38$ 単位/月/人から $0.08 \pm 0.15$ 単位/月/人と有意 $(P<0.05)$ に減少した. Ht 值は PPHD 開始前 $22.1 \pm$ $3.9 \%, 5$ か月後 $24.9 \pm 3.9 \%$ と有意 $(P<0.05)$ に上昇し, 血清総蛋白の増加を伴ったが, 鉄代謝, $\beta_{2}$-microglobulin, PTH, Al, 小分子量物質レベルには変化を認めなかった. PPHD 群の中で Ht の上昇した 7 例では, 血清クレアチニン 值, 総蛋白, $\mathrm{Ca}$ 濃度の上昇がみられ, 血清 $\mathrm{Al}$ 濃度が減少した。ただし $\Delta \mathrm{Ht}$ と $\Delta \mathrm{Al}$ の間には, 有意な相関を認めな かった。 PPHD 施行により著明に貧血が改善した 1 例では膜面積依存性に $\mathrm{Ht}$ 值の上昇を認めた。 以上の結果より， 今回我々の用いたセルロース膜系蛋白漏出型ダイアライザーによる透析は, 貧血を高率に改善したが, 炎の機序とし て鉄代謝, $\beta_{2}$-microglobulin, PTH, AI などの関与は希薄で中分子領域から小分子蛋白領域の uremic toxin (s) の関与 が推測された。

\section{Long-term clinical effects of protein permeable hemodialysis (PPHD) on the anemia in the patients undergoing maintenance hemodialysis}

Koshi Ueno, Ariyoshi Watanabe, Hideo Aoyagi, Atushi Kotoda, Keisuke Kotoda, M. D.,Eiji Kusano, M. D.* Yasushi Asano, M. D.*

Koganei Clinic, Kidney Center, Jichi Medical School*

To evaluate the effect and the mechanism of action of PPHD on the anemia in patients undergoing maintenance hemodialysis, serial measurements of hematocrit and other hematological parameters were performed in PPHD group $(n=15)$ and regular HD group $(n=15)$. Fifteen patients who received PPHD had either drug-resistant anemia or HD amyloidosis. In the PPHD group, improvement of anemia was recongnized in 7 of 15 patients $(47 \%)$, and the blood transfusion rate was significantly reduced from $0.26 \pm 0.38$ to $0.08 \pm 0.15$ units/month/ person $(p<0.05)$.

The hematocrit rose from $22.1 \pm 3.9$ to $24.9 \pm 3.9 \%(p<0.05)$ after 5 months of treatment. Total protein rose from $6.3 \pm 0.6$ to $6.5 \pm 0.5 \mathrm{~g} / \mathrm{d} l(\mathrm{p}<0.05)$. There were no significant changes in iron metabolism, or the serum levels of $\beta_{2}$-microglobulin, PTH, aluminum and small molecular substances. Seven patients who had elevations of hematocrit in the PPHD group showed significant rises in serum creatinine, total protein and total calcium with a concomitant decrease in serum aluminum level. However, there was no significant correlation between hematocrit and serum aluminum level. There was a surface area-dependent rise in hematocrit when remarkable improvement in anemia occurred after introduction of PPHD. From these results, PPHD seems to be effective in : improving anemia in patients undergoing maintenance hemodialysis.

上野 幸司 小金井クリニック

干 329-04 下都賀郡国分寺町駅東 5-13-16 (0285-44-8345)
Uremic toxin(s) from the middle molecular range to the large molecular range might be more important 
than well-known uremic toxins such as $\beta_{2}$-microglobulin, PTH and aluminum.

\section{緒言}

貧血は長期透析患者に扔ける主要合併症の一つで，そ の原因は多岐にわたっているが，血液浄化法という側面 からは, 代謝産物の蓄積, 透析効率, 造血因子の袈失, 水処理不備による溶血，更には残血による失血などが重 要である, 最近蛋白漏出型ダイアライザーを用いた血液 透析 (protein permeable hemodialysis, PPHD) や血液 濾過透析 (PPHDF) が透析患者の貧血に有効とする報 告 ${ }^{1 \sim 4)}$ がみられているが, その機序の詳細は必ずしも明か ではない。そこで今回我々は PPHD を長期間継続する 機会を得たので，主に貧血に対する効果について，通常 セルロース膜での血液透析と比較検討し，併せて，その 機序についても考察した.

\section{対象・方法}

対象は当院で週 3 回, $4 \sim 5$ 時間/回の透析を受けてい る安定期の長期透析患者 30 例である（表 1 ）。1 15 例（男 9, 女 6 )にセルロース系蛋白漏出型ダイアライザー(ク リランス® $\mathrm{S} 12 \mathrm{~W}$, クリランス® $\mathrm{S} 15 \mathrm{w} ，$ テルモ社製)を使 用し (PPHD 群)，他の 15 例 (男 12 ，女 3 ) は通常セル ロース膜（HD 群）で透析を施行した。PPHD 群の年齢 は $48.7 \pm 12.7$ 歳, 透析歴は $5.6 \pm 3.4$ 年である.一方 $\mathrm{HD}$ 群の年齢と透析歴は $54.6 \pm 13.8$ 歳, $6.0 \pm 2.0$ 年であっ た。年齢のみ HD 群で PPHD 群に比べ高い以外, 透析 歷, 透析時間, 血流量, 膜面積などの透析条件には両群 で差はなかった.PPHD 群には治療抵抗性の貧血のため 輸血を要する症例や手根管症候群，搔痒症を合併した症 例を選んだ。上記条件下で PPHD, HD を各々 7 か月間 継続し，施行前後の各種パラメーターを比較検討した. 結果は, すべて mean \pm SD で表示し, 統計処理は Student's t-test により検定した。

\section{結果}

図 1 に両群のへマクリット（Ht） 值の推移を示す. PPHD 群では施行前 $\mathrm{Ht}$ 值は $22.1 \pm 3.9 \%$ であったが 5 か月後 $24.9 \pm 3.9 \%$ まで有意 $(\mathrm{p}<0.05)$ に上昇し，以後 その状態を持続している。一方 HD 群での $\mathrm{Ht}$ 值は施行 前後で有意な変化を示していない.

図 2 にPPHD 群の 1 例で著明に貧血が改善した症例 を示す. PPHD 施行前貧血は anabolic steroid, 鉄剤, ビタミン剤に抵抗性で 1984 年から 36 か月間に計 27 単 位の輸血が行われた。

1986 年 9 月より EVAL-C 膜を使用するようになって からは，6 か月で Ht 值が $18 \%$ から $23 \%$ に上昇してい る. しかし血清りン值が $6 \sim 7 \mathrm{mg} / \mathrm{d} l$ と高值なためリン 除去率の高いダイアライザー(クリランス $\left.{ }^{\circledR} \mathrm{S} 12 \mathrm{~W}\right)$ に変
表 1 対象症例の background

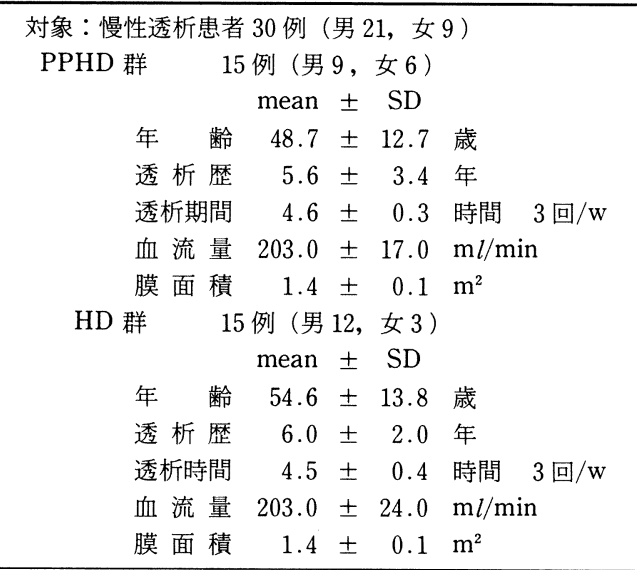

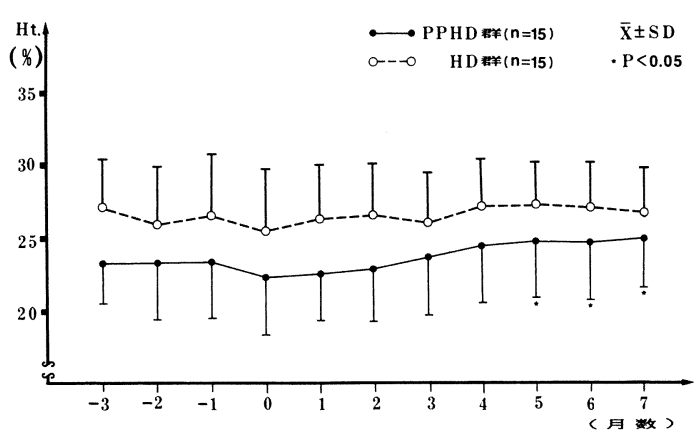

図 1 PPHD 群と HD 群の $\mathrm{Ht}$ 值の推移

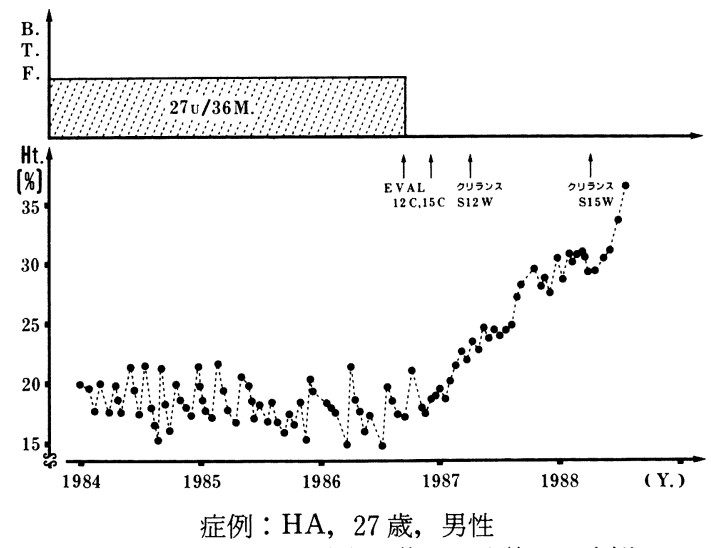

図 2 PPHD により貧血が著明に改善した症例 


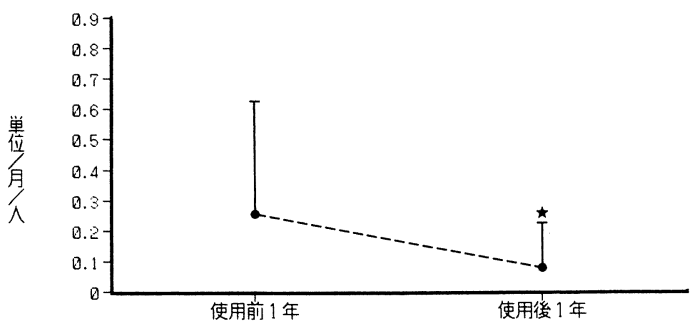

図 3 PPHD 群における輸血量の変化 $\mathrm{n}=15$, mean $\pm \mathrm{SD}, * \mathrm{p}<0.05$

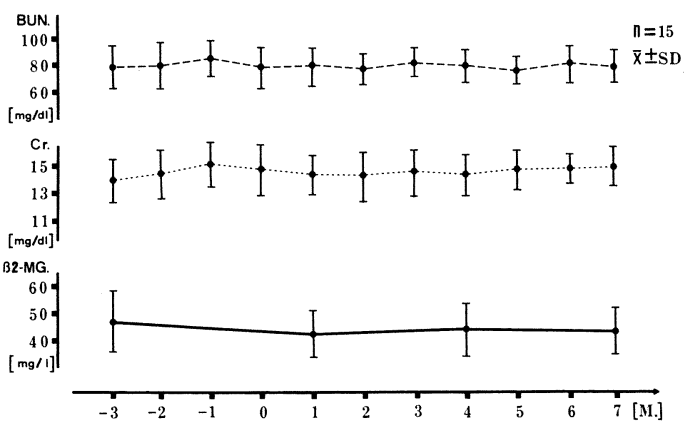

図 4 PPHD 群における $\mathrm{BUN}, \mathrm{Cr}, \beta_{2}-\mathrm{MG}$ の 推移

除去率の高いダイアライザー (クリランス $\left.{ }^{\circledR} \mathrm{S} 12 \mathrm{~W}\right)$ に変 更したところ血清りン值は $4 \sim 5 \mathrm{mg} / \mathrm{d} l$ と安定した. $\mathrm{Ht}$ 值は $23 \%$ から急速に上昇し $30 \%$ 越えるようになった が, 膜面積を上げると更に上昇し, 15 か月後には $36 \%$ に 至っている。

図 3 は PPHD 群における患者一人当りの月平均輸血 量を示している.PPHD 施行前一年間の輸血量は $0.26 \pm$ 0.38 単位/月/人であったが施行後の一年間は $0.08 \pm$ 0.15 単位/月/人と有意 $(\mathrm{P}<0.05)$ に減少している.

図 4 に PPHD 群の BUN, Cr, $\beta_{2}$-microglobulin の推 移を示す. PPHD 施行前, 施行後のいずれのパラメータ も有意な変動を示していない.また図には示さないが $\mathrm{HD}$ 群においても $\mathrm{BUN}, \mathrm{Cr}, \beta_{2}$-microglobulin に変化を 認めなかつた。

図 5 と表 2 はPPD 群における各種パラメーターの 変化を示しているが, 施行開始時を含む 3 か月の平均と 施行後 $4 \sim 7$ か月までの 3 か月の平均を比較検討したも のである. 赤血球数, へモグロビン, $\mathrm{Ht}$ 值は各々, $6.2 \%$, $8.1 \%, 7.4 \%$ と有意に増加したが, MCV, MCH, MCHC は有意の変化を示さなかった.また網状赤血球, 血清鉄, 総鉄結合能,フェリチン值も有意な動きを示さなかった。 その他のパラメーターでは, 血清総蛋白が $6.3 \mathrm{~g} / \mathrm{d} l$ から
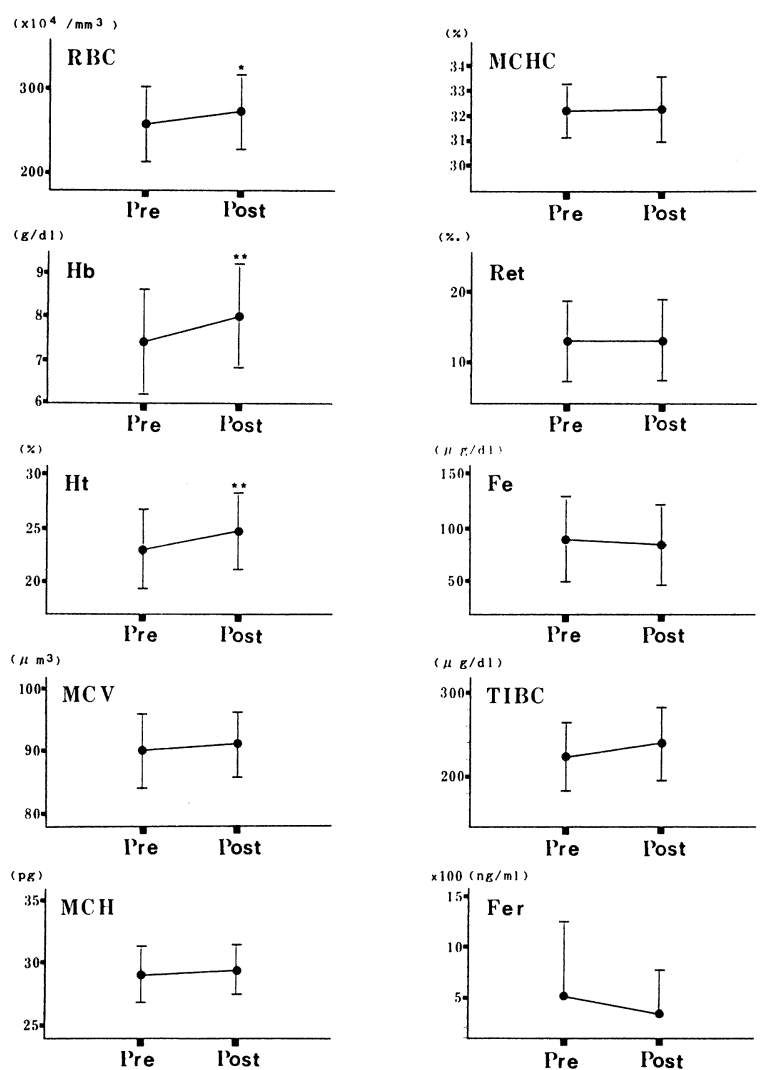

図 5 PPHD 群における各種 パラメーターの比較

Pre 施行前 3 か月 mean \pm SD $* \mathrm{p}<0.05$

Post 施行後 3 か月 mean $\pm \mathrm{SD} * * \mathrm{p}<0.01$

$6.5 \mathrm{~g} / \mathrm{d} l$ に増加しているが，血清 $\mathrm{Al}, \mathrm{PTH}$ レベルには 変化がなく, 体重, 血圧, 心胸比などにも変化はみられ なかった。しかし PPHD 群の中には $\mathrm{Ht}$ 值が施行前に 比べて $10 \%$ 以上増加した群 $(\mathrm{n}=7)$ と変化がみられな かった群 $(\mathrm{n}=8)$ があり, それぞれの群における各種パ ラメーターの変化は表 3 に示されている. Ht 值上昇群で は, 赤血球数, へモグロビン, $\mathrm{Ht}$ 值の増加に伴って血清 クレアチニン值, 総蛋白, $\mathrm{Ca}$ 濃度が上昇し, 更に透析後 の血圧が上昇したが，血清 $\mathrm{Al}$ 濃度は減少した。ただし， 個々の症例では $\Delta \mathrm{Ht}$ と $\Delta \mathrm{Al}$ の間には有意の相関は認め なかった. Ht 不変群では, いづれのパラメーターにも施 行前後で変化を認めなかった。他方 HD 群（表 4 ）にお いては, PTHレベルに上昇がみられたが, 他のパラメー ターには変化を認めなかった。

\section{考案}

最近, 各種の膜素材による high performance membrane (HPM) が開発され，小，中分子領域の物質のみ 
表 2 PPHD 群における各種パラメーターの比較

\begin{tabular}{|c|c|c|c|c|}
\hline 項 目 & （単位） & $\begin{array}{c}\text { 施行前 } 3 \mathrm{M} \text {. } \\
\text { mean } \pm \mathrm{SD}\end{array}$ & $\begin{array}{c}\text { 施行後 } 3 \mathrm{M} . \\
\text { mean } \pm \mathrm{SD}\end{array}$ & 有意差検定 \\
\hline $\mathrm{RBC}$ & $\left(\mathrm{x} 10^{4} / \mathrm{mm}^{3}\right)$ & $257.3 \pm 44.9$ & $273.3 \pm 44.7$ & $\mathrm{p}<0.05$ \\
\hline $\mathrm{Hb}$ & $(\mathrm{g} / \mathrm{d} l)$ & $7.4 \pm 1.2$ & $8.0 \pm 1.2$ & $\mathrm{p}<0.01$ \\
\hline $\mathrm{Ht}$ & $(\%)$ & $23.0 \pm 3.7$ & $24.7 \pm 3.6$ & $\mathrm{p}<0.01$ \\
\hline $\mathrm{MCV}$ & $\left(\mu \mathrm{m}^{3}\right)$ & $90.0 \pm 5.8$ & $90.9 \pm 5.1$ & \\
\hline $\mathrm{MCH}$ & (pg) & $29.0 \pm 2.2$ & $29.4 \pm 2.0$ & \\
\hline $\mathrm{MCHC}$ & (\%) & $32.2 \pm 1.1$ & $32.3 \pm 1.3$ & \\
\hline Ret & $(\%)$ & $13.0 \pm 5.8$ & $13.1 \pm 5.8$ & \\
\hline BUN & $(\mathrm{mg} / \mathrm{d} l)$ & $78.4 \pm 12.9$ & $77.2 \pm 12.8$ & \\
\hline $\mathrm{Cr}$ & $(\mathrm{mg} / \mathrm{d} l)$ & $14.1 \pm 1.8$ & $14.5 \pm 1.5$ & \\
\hline $\mathrm{TP}$ & $(\mathrm{g} / \mathrm{d} l)$ & $6.3 \pm 0.6$ & $6.5 \pm 0.5$ & $\mathrm{p}<0.05$ \\
\hline $\mathrm{Ca}$ & $(\mathrm{mEq} / l)$ & $4.6 \pm 0.3$ & $4.6 \pm 0.4$ & \\
\hline $\mathrm{P}$ & $(\mathrm{mg} / \mathrm{d} l)$ & $4.4 \pm 1.0$ & $4.4 \pm 1.1$ & \\
\hline $\mathrm{Fe}$ & $(\mu \mathrm{g} / \mathrm{d} l)$ & $89.1 \pm 39.8$ & $84.3 \pm 37.5$ & \\
\hline TIBC & $(\mu \mathrm{g} / \mathrm{d} l)$ & $223.7 \pm 41.0$ & $238.8 \pm 43.8$ & \\
\hline Ferritin & $(\mathrm{ng} / \mathrm{m} l)$ & $514.6 \pm 744.1$ & $341.2 \pm 422.3$ & \\
\hline T-Chol & $(\mathrm{mg} / \mathrm{d} l)$ & $159.3 \pm 23.0$ & $159.0 \pm 27.9$ & \\
\hline TG & $(\mathrm{mg} / \mathrm{d} l)$ & $155.8 \pm 83.9$ & $160.0 \pm 96.0$ & \\
\hline $\mathrm{Al}$ & $(\mu \mathrm{g} / \mathrm{d} l)$ & $12.9 \pm 11.2$ & $7.8 \pm 4.1$ & \\
\hline$\beta_{2}-\mathrm{MG}$ & $(\mathrm{mg} / l)$ & $46.8 \pm 12.2$ & $43.7 \pm 9.1$ & \\
\hline PTH & $(\mathrm{ng} / \mathrm{m} l)$ & $4.8 \pm 3.4$ & $6.6 \pm 5.4$ & \\
\hline 透析前体重 & $(\mathrm{kg})$ & $54.0 \pm 8.8$ & $55.0 \pm 9.8$ & \\
\hline 透析後体重 & $(\mathrm{kg})$ & $51.7 \pm 8.5$ & $52.3 \pm 9.4$ & \\
\hline 透析前血圧 & $(\mathrm{mmHg})$ & $145 \pm 25 / 83 \pm 12$ & $141 \pm 22 / 82 \pm 11$ & \\
\hline 透析後血圧 & $(\mathrm{mmHg})$ & $130 \pm 19 / 79 \pm 11$ & $128 \pm 14 / 81 \pm 11$ & \\
\hline CTR & (\%) & $51.9 \pm 4.8$ & $50.8 \pm 4.9$ & \\
\hline
\end{tabular}

ならず $\beta_{2}$-microglobulin をはじめとする小分子蛋白領 域の物質の除去率が向上してきている.透析アミロイ ドーシス貧血, 関節痛や搔痒症などに一部有効との報 告 ${ }^{5 \sim 7}$ がなされているが, いかなる機序で上記症状及び病 態を改善するのか必ずしも明らかではない. 種々の HPM を使用した HD や HDF の貧血改善効果は $25 \%$ 〜 40\%程度の患者沫認められているが，その際，蛋白喪 失が多い膜ほど改善効果は少ないとされている ${ }^{8)}$.今回 の検討では 15 例中 7 例，すなわち約 $47 \%$ と比較的高率 に貧血の改善を認めた. 貧血改善例では血清総蛋白が上 昇し, 不変例では総蛋白に変化を認めず前述の所見を裏 付けるものといえよう.

現在, 造血抑制性因子と考えられているものとしては, spermine $^{9)}$, ribonuclease ${ }^{10)}$, 中分子量物質 $\mathrm{II}_{a}{ }^{11)}, \mathrm{PTH}^{12)}$
や $\mathrm{Al}^{13)}$, 最近では $\beta_{2}$-microglobulin も挙げられている. 斉藤ら ${ }^{14)}$ は分子量 1500 以上の分画にプロテアーゼで不 活性化される抑制因子を, Freedman ら ${ }^{15}$ は分子量 10 万 以上の蛋白分画に抑制因子が存在すると報告している.

また McGonigle ら ${ }^{16}$ は尿毒症患者血清中にエリスロポ エチン（Epo）抑制因子の存在を指摘し，Epo の造血作 用が阻害されると報告している。

血清 $\mathrm{Al}$ による貧血は鉄欠乏によらない小球性低色素 性貧血で，へム合成や鉄代謝に関わる delta aminolevulinic acid dehydrogenase ${ }^{17)} や$ ferroxidase $^{18)}$ などが阻害されたり，赤芽球への鉄取り込みや鉄の利用 が阻害されて惹起されるという ${ }^{19)}$. 我々の成績では PPHD 群の $\mathrm{Ht}$ 上昇例で血清 $\mathrm{Al}$ 濃度が低下したもの の, $\Delta \mathrm{Al}$ と $\Delta \mathrm{Ht}$ 間には相関を認めず, $\mathrm{MCV}, \mathrm{MCH}$ に 
表 $3 \mathrm{Ht}$ 上昇群と $\mathrm{Ht}$ 不変群における各種パラメーターの比較

\begin{tabular}{|c|c|c|c|c|c|}
\hline 項 目 & (単位) & & $\begin{array}{c}\mathrm{Ht} \text { 上昇群 }(\mathrm{n}=7) \\
\text { mean } \pm \mathrm{SD}\end{array}$ & $\begin{array}{c}\mathrm{Ht} \text { 上昇群 }(\mathrm{n}=8) \\
\text { mean } \pm \mathrm{SD}\end{array}$ & 有意差検定 \\
\hline $\mathrm{RBC}$ & $\left(\mathrm{x} 10^{4} / \mathrm{mm}^{3}\right)$ & $\begin{array}{l}\text { 施行前 } 3 \mathrm{M} . \\
\text { 施行後 } 3 \mathrm{M} .\end{array}$ & $\begin{array}{c}247.8 \pm 35.0 \\
282.8 \pm 29.5 \\
* * * *\end{array}$ & $\begin{array}{l}265.5 \pm 49.0 \\
264.8 \pm 51.7\end{array}$ & \\
\hline $\mathrm{Hb}$ & $(\mathrm{g} / \mathrm{d} l)$ & $\begin{array}{l}\text { 施行前 } 3 \mathrm{M} \text {. } \\
\text { 施行後 } 3 \mathrm{M} \text {. }\end{array}$ & $\begin{array}{l}7.2 \pm 0.9 \\
8.2 \pm 0.8 \\
* * * *\end{array}$ & $\begin{array}{l}7.6 \pm 1.3 \\
7.8 \pm 1.4\end{array}$ & \\
\hline $\mathrm{Ht}$ & $(\%)$ & $\begin{array}{l}\text { 施行前 } 3 \mathrm{M} . \\
\text { 施行後 } 3 \mathrm{M} \text {. }\end{array}$ & $\begin{array}{c}22.7 \pm 2.9 \\
25.8 \pm 1.9 \\
* * * *\end{array}$ & $\begin{array}{l}23.3 \pm 4.1 \\
23.8 \pm 4.3\end{array}$ & $*$ \\
\hline $\mathrm{MCV}$ & $\left(\mu \mathrm{m}^{3}\right)$ & $\begin{array}{l}\text { 施行前 } 3 \mathrm{M} \text {. } \\
\text { 施行後 } 3 \mathrm{M} \text {. }\end{array}$ & $\begin{array}{l}92.0 \pm 5.0 \\
91.6 \pm 5.5\end{array}$ & $\begin{array}{l}88.3 \pm 5.7 \\
90.2 \pm 4.4\end{array}$ & $* * *$ \\
\hline $\mathrm{MCH}$ & $(\mathrm{pg})$ & $\begin{array}{l}\text { 施行前 } 3 \mathrm{M} \text {. } \\
\text { 施行後 } 3 \mathrm{M} \text {. }\end{array}$ & $\begin{array}{l}29.3 \pm 2.1 \\
29.1 \pm 2.3\end{array}$ & $\begin{array}{l}28.7 \pm 2.1 \\
29.6 \pm 1.4 \\
*\end{array}$ & \\
\hline $\mathrm{MCHC}$ & $(\%)$ & $\begin{array}{l}\text { 施行前 } 3 \mathrm{M} . \\
\text { 施行後 } 3 \mathrm{M} \text {. }\end{array}$ & $\begin{array}{l}31.8 \pm 1.2 \\
31.8 \pm 1.4\end{array}$ & $\begin{array}{l}32.5 \pm 0.9 \\
32.8 \pm 0.8\end{array}$ & $\begin{array}{ll}* & * \\
* * * * *\end{array}$ \\
\hline Ret & $(\%)$ & $\begin{array}{l}\text { 施行前 } 3 \mathrm{M} . \\
\text { 施行後 } 3 \mathrm{M} \text {. }\end{array}$ & $\begin{array}{l}14.1 \pm 6.4 \\
12.5 \pm 4.7\end{array}$ & $\begin{array}{l}12.1 \pm 4.9 \\
13.5 \pm 6.3\end{array}$ & \\
\hline BUN & $(\mathrm{mg} / \mathrm{d} l)$ & $\begin{array}{l}\text { 施行前 } 3 \mathrm{M} \text {. } \\
\text { 施行後 } 3 \mathrm{M} \text {. }\end{array}$ & $\begin{array}{l}78.1 \pm 14.2 \\
74.1 \pm 13.7\end{array}$ & $\begin{array}{l}78.7 \pm 10.9 \\
80.0 \pm 10.6\end{array}$ & $*$ \\
\hline $\mathrm{Cr}$ & $(\mathrm{mg} / \mathrm{d} l)$ & $\begin{array}{l}\text { 施行前 } 3 \mathrm{M} . \\
\text { 施行後 } 3 \mathrm{M} \text {. }\end{array}$ & $\begin{array}{l}13.1 \pm 1.6 \\
14.3 \pm 1.4 \\
* * *\end{array}$ & $\begin{array}{l}14.9 \pm 1.4 \\
14.7 \pm 1.6\end{array}$ & $* * * *$ \\
\hline $\mathrm{TP}$ & $(\mathrm{g} / \mathrm{d} l)$ & $\begin{array}{l}\text { 施行前 } 3 \mathrm{M} . \\
\text { 施行後 } 3 \mathrm{M} \text {. }\end{array}$ & $\begin{array}{l}6.2 \pm 0.5 \\
6.5 \pm 0.5 \\
*\end{array}$ & $\begin{array}{l}6.5 \pm 0.6 \\
6.6 \pm 0.4\end{array}$ & * \\
\hline $\mathrm{Ca}$ & $(\mathrm{mEq} / l)$ & $\begin{array}{l}\text { 施行前 } 3 \mathrm{M} . \\
\text { 施行後 } 3 \mathrm{M} \text {. }\end{array}$ & $\begin{array}{l}4.5 \pm 0.2 \\
4.7 \pm 0.3 \\
*\end{array}$ & $\begin{array}{l}4.6 \pm 0.4 \\
4.5 \pm 0.4\end{array}$ & * \\
\hline $\mathrm{P}$ & $(\mathrm{mg} / \mathrm{d} l)$ & $\begin{array}{l}\text { 施行前 } 3 \mathrm{M} \text {. } \\
\text { 施行後 } 3 \mathrm{M} \text {. }\end{array}$ & $\begin{array}{l}4.6 \pm 1.0 \\
4.5 \pm 0.9\end{array}$ & $\begin{array}{l}4.3 \pm 1.0 \\
4.3 \pm 1.3\end{array}$ & \\
\hline $\mathrm{Fe}$ & $(\mu \mathrm{g} / \mathrm{d} l)$ & $\begin{array}{l}\text { 施行前 } 3 \mathrm{M} \text {. } \\
\text { 施行後 } 3 \mathrm{M} \text {. }\end{array}$ & $\begin{array}{l}96.1 \pm 50.7 \\
84.5 \pm 45.6\end{array}$ & $\begin{array}{l}83.2 \pm 22.5 \\
84.2 \pm 25.8\end{array}$ & \\
\hline TIBC & $(\mu \mathrm{g} / \mathrm{d} l)$ & $\begin{array}{l}\text { 施行前 } 3 \mathrm{M} \text {. } \\
\text { 施行後 } 3 \mathrm{M} \text {. }\end{array}$ & $\begin{array}{l}207.7 \pm 49.4 \\
207.5 \pm 30.1\end{array}$ & $\begin{array}{l}232.0 \pm 43.5 \\
232.3 \pm 49.0\end{array}$ & \\
\hline Ferritin & $(\mathrm{ng} / \mathrm{m} l)$ & $\begin{array}{l}\text { 施行前 } 3 \mathrm{M} \text {. } \\
\text { 施行後 } 3 \mathrm{M} \text {. }\end{array}$ & $\begin{array}{l}598.4 \pm 902.6 \\
474.3 \pm 557.4\end{array}$ & $\begin{array}{l}415.6 \pm 416.2 \\
227.1 \pm 165.9\end{array}$ & \\
\hline T-Chol & $(\mathrm{mg} / \mathrm{d} l)$ & $\begin{array}{l}\text { 施行前 } 3 \mathrm{M} \text {. } \\
\text { 施行後 } 3 \mathrm{M} \text {. }\end{array}$ & $\begin{array}{l}152.5 \pm 22.4 \\
147.2 \pm 20.7\end{array}$ & $\begin{array}{l}166.0 \pm 20.1 \\
171.0 \pm 28.0\end{array}$ & $\begin{array}{l}* \\
* * * * *\end{array}$ \\
\hline TG & $(\mathrm{mg} / \mathrm{d} l)$ & $\begin{array}{l}\text { 施行前 } 3 \mathrm{M} \text {. } \\
\text { 施行後 } 3 \mathrm{M} \text {. }\end{array}$ & $\begin{array}{l}113.0 \pm 51.7 \\
100.7 \pm 47.0\end{array}$ & $\begin{array}{l}193.5 \pm 86.4 \\
212.2 \pm 97.8\end{array}$ & $\begin{array}{llll}* & * & * & * \\
* & * & * & *\end{array}$ \\
\hline $\mathrm{Al}$ & $(\mu \mathrm{g} / \mathrm{d} l)$ & $\begin{array}{l}\text { 施行前 } 3 \mathrm{M} . \\
\text { 施行後 } 3 \mathrm{M} \text {. }\end{array}$ & $\begin{array}{l}13.7 \pm 9.4 \\
5.8 \pm 2.9 \\
*\end{array}$ & $\begin{array}{l}12.5 \pm 11.3 \\
10.0 \pm 4.3\end{array}$ & $*$ \\
\hline$\beta_{2}-\mathrm{MG}$ & $(\mathrm{mg} / l)$ & $\begin{array}{l}\text { 施行前 } 3 \mathrm{M} \text {. } \\
\text { 施行後 } 3 \mathrm{M} \text {. }\end{array}$ & $\begin{array}{l}44.8 \pm 8.0 \\
43.4 \pm 3.0\end{array}$ & $\begin{array}{l}47.9 \pm 14.3 \\
44.0 \pm 11.3\end{array}$ & \\
\hline PTH & $(\mathrm{ng} / \mathrm{m} l)$ & $\begin{array}{l}\text { 施行前 } 3 \mathrm{M} \text {. } \\
\text { 施行後 } 3 \mathrm{M} \text {. }\end{array}$ & $\begin{array}{l}6.2 \pm 3.9 \\
8.1 \pm 8.3\end{array}$ & $\begin{array}{l}3.7 \pm 2.3 \\
5.4 \pm 3.1\end{array}$ & \\
\hline 透析前体重 & $(\mathrm{kg})$ & $\begin{array}{l}\text { 施行前 } 3 \mathrm{M} \text {. } \\
\text { 施行後 } 3 \mathrm{M} \text {. }\end{array}$ & $\begin{array}{l}52.7 \pm 7.2 \\
54.0 \pm 7.8\end{array}$ & $\begin{array}{l}55.3 \pm 10.2 \\
56.0 \pm 11.8\end{array}$ & \\
\hline 透析後体重 & $(\mathrm{kg})$ & $\begin{array}{l}\text { 施行前 } 3 \mathrm{M} \text {. } \\
\text { 施行後 } 3 \mathrm{M} \text {. }\end{array}$ & $\begin{array}{l}50.2 \pm 6.6 \\
51.3 \pm 5.6\end{array}$ & $\begin{array}{l}53.1 \pm 10.0 \\
53.4 \pm 11.5\end{array}$ & \\
\hline 透析前血圧 & $(\mathrm{mmHg})$ & $\begin{array}{l}\text { 施行前 } 3 \mathrm{M} \text {. } \\
\text { 施行後 } 3 \mathrm{M} \text {. }\end{array}$ & $\begin{array}{l}138 \pm 31 / 83 \pm 11 \\
139 \pm 26 / 84 \pm 11\end{array}$ & $\begin{array}{l}151 \pm 21 / 82 \pm 12 \\
143 \pm 15 / 80 \pm 10\end{array}$ & $*$ \\
\hline 透析後血圧 & $(\mathrm{mmHg})$ & $\begin{array}{l}\text { 施行前 } 3 \mathrm{M} \text {. } \\
\text { 施行後 } 3 \mathrm{M} \text {. }\end{array}$ & $\begin{array}{c}123 \pm 17 / 76 \pm 10 \\
131 \pm 13 / 83 \pm 12 \\
*, \quad *\end{array}$ & $\begin{array}{l}137 \pm 17 / 81 \pm 10 \\
126 \pm 13 / 79 \pm 8\end{array}$ & $* * * *, \quad *$ \\
\hline CTR & $(\%)$ & $\begin{array}{l}\text { 施行前 } 3 \mathrm{M} \text {. } \\
\text { 施行後 } 3 \mathrm{M} \text {. }\end{array}$ & $\begin{array}{l}51.7 \pm 4.6 \\
50.1 \pm 4.3\end{array}$ & $\begin{array}{l}52.1 \pm 4.7 \\
51.5 \pm 5.0\end{array}$ & \\
\hline
\end{tabular}

$* \mathrm{p}<0.05, * * \mathrm{p}<0.01, * * * \mathrm{p}<0.005, * * * * \mathrm{p}<0.001$ 
表 4 HD 群における各種パラメーターの比較

\begin{tabular}{|c|c|c|c|c|}
\hline 項 目 & （単位） & $\begin{array}{c}\text { 施行前 } 3 \mathrm{M} \text {. } \\
\text { mean } \pm \mathrm{SD}\end{array}$ & $\begin{array}{c}\text { 施行後 } 3 \mathrm{M} \text {. } \\
\text { mean } \pm \mathrm{SD}\end{array}$ & 有意差検定 \\
\hline $\mathrm{RBC}$ & $\left(\mathrm{x} 10^{4} / \mathrm{mm}^{3}\right)$ & $295.0 \pm 43.4$ & $303.0 \pm 41.0$ & \\
\hline $\mathrm{Hb}$ & $(\mathrm{g} / \mathrm{d} l)$ & $8.5 \pm 1.2$ & $8.6 \pm 1.2$ & \\
\hline $\mathrm{Ht}$ & $(\%)$ & $26.3 \pm 3.8$ & $27.0 \pm 3.5$ & \\
\hline $\mathrm{MCV}$ & $\left(\mu \mathrm{m}^{3}\right)$ & $89.5 \pm 6.6$ & $89.2 \pm 7.1$ & \\
\hline $\mathrm{MCH}$ & (pg) & $28.8 \pm 2.7$ & $28.6 \pm 2.9$ & \\
\hline $\mathrm{MCHC}$ & $(\%)$ & $32.3 \pm 1.0$ & $32.0 \pm 1.2$ & \\
\hline Ret & $(\%)$ & $11.2 \pm 5.3$ & $12.1 \pm 5.6$ & \\
\hline BUN & $(\mathrm{mg} / \mathrm{d} l)$ & $81.4 \pm 15.1$ & $82.4 \pm 14.8$ & \\
\hline $\mathrm{Cr}$ & $(\mathrm{mg} / \mathrm{d} l)$ & $14.4 \pm 2.6$ & $14.9 \pm 2.0$ & \\
\hline $\mathrm{TP}$ & $(\mathrm{g} / \mathrm{d} l)$ & $6.4 \pm 0.4$ & $6.4 \pm 0.4$ & \\
\hline $\mathrm{Ca}$ & $(\mathrm{mEq} / l)$ & $4.5 \pm 0.3$ & $4.5 \pm 0.3$ & \\
\hline$P$ & $(\mathrm{mg} / \mathrm{d} l)$ & $4.8 \pm 1.1$ & $4.6 \pm 1.2$ & \\
\hline $\mathrm{Fe}$ & $(\mu \mathrm{g} / \mathrm{d} l)$ & $82.7 \pm 37.4$ & $77.3 \pm 31.2$ & \\
\hline TIBC & $(\mu \mathrm{g} / \mathrm{d} l)$ & $216.0 \pm 27.7$ & $225.0 \pm 35.4$ & \\
\hline Ferritin & $(\mathrm{ng} / \mathrm{m} l)$ & $322 \pm 435$ & $214 \pm 328$ & \\
\hline T-Chol & $(\mathrm{mg} / \mathrm{d} l)$ & $145.0 \pm 28.0$ & $149.0 \pm 32.3$ & \\
\hline TG & $(\mathrm{mg} / \mathrm{d} l)$ & $123.0 \pm 83.8$ & $118.0 \pm 76.2$ & \\
\hline AI & $(\mu \mathrm{g} / \mathrm{d} l)$ & $9.4 \pm 5.2$ & $9.3 \pm 2.6$ & \\
\hline$\beta_{2}-\mathrm{MG}$ & $(\mathrm{mg} / l)$ & $38.0 \pm 5.0$ & $43.5 \pm 6.2$ & \\
\hline PTH & $(\mathrm{ng} / \mathrm{m} l)$ & $3.00 \pm 2.05$ & $4.73 \pm 2.60$ & $\mathrm{p}<0.05$ \\
\hline 透析前体重 & $(\mathrm{kg})$ & $54.2 \pm 8.0$ & $55.7 \pm 8.2$ & \\
\hline 透析後体重 & $(\mathrm{kg})$ & $51.7 \pm 7.5$ & $52.8 \pm 7.5$ & \\
\hline 透析前血圧 & $(\mathrm{mmHg})$ & $148 \pm 17 / 86 \pm 11$ & $157 \pm 20 / 86 \pm 12$ & $\mathrm{p}<0.01$ \\
\hline 透析後血圧 & $(\mathrm{mmHg})$ & $139 \pm 14 / 83 \pm 10$ & $133 \pm 12 / 81 \pm 9$ & \\
\hline CTR & $(\%)$ & $51.2 \pm 7.2$ & $52.1 \pm 6.2$ & \\
\hline
\end{tabular}

も変化が認められなかったことから，PPHD による $\mathrm{Al}$ の除去が Ht 值の上昇の主因とは考えられなかった.

$\beta_{2}$-microglobulin は透析アミロイドーシスの原因物 質 ${ }^{20)}$ として注目されているが，骨髄抑制性の uremic toxin として働く可能性も示唆されている. 関口ら ${ }^{21}$ は CFU-E（赤芽球コロニー形成細胞）培養系を用いた in vitro の検討で $\beta_{2}$-microglobulin に骨髄抑制作用を認め なかったとしている. 今回の検討でも PPHD 施行前後 で $\beta_{2}$-microglobulin レベルは全く変化せず, 貧血への関 与は希薄と考えられた。

PTH も骨髄抑制性の uremic toxin のひとつと考えら れているが，ヒト未梢血やマウス骨髄の BFU-E(赤芽球 コロニー群形成細胞）を著明に抑制するが CFU-E は抑 制しない ${ }^{22}$. Ca イオンの赤芽球内流入を増加して赤芽球
膜の脆弱性を高める可能性も示唆されている23).さらに 血小板内の ADP, fibrin, collagen 凝集能を低下させ出 血性素因をもたらして貧血を助長することも知られてい る. PTH は分子量 9500 であり PPHD にて一部除き得 るが今回の検討では変化がなく貧血改善への関与は希薄 であろう。

今回，小分子量物質の spermine や大分子量物質の ribonuclease レベルは検討しておらず PPHD の貧血改 善効果への関与は不明であるが，貧血が著明に改善した 症例（図 2 ）では膜面積依存性に貧血が改善している。 このことは中分子領域から大分子領域の物質が除去され 貧血が改善したことを示唆しているが、今後 PPHD の 中止, 再開による Ht 值の変動, 骨髄抑制因子の変動な ぞを検討する必要があろう。 
最近, 遺伝子工学によって $\mathrm{rEPO}$ が量産され腎性貧血 が確実に改善するようになり ${ }^{24)}$, 各種 uremic toxin の 貧血への関与の重要性は薄らいできた感があるが, $\mathrm{rEPO}$ を十分投与した段階でなお，これらの物質が造血 障害に影響を及ぼすかどうかは今後の問題であろう.

\section{結語}

治療抵抗性の貧血や手根管症候群を有する維持透析患 者に PPHD を施行し， 7 か月間にわたる変化を観察し たが, 約 47\%に貧血の改善を認め, かつ輸血量も減少し た. PPHD の貧血改善の機序として鉄代謝, $\beta_{2}$-microglobulin, $\mathrm{PTH}, \mathrm{Al}$ などの関与は希薄で，中分子領域から 小分子蛋白領域の uremic toxin (s) の関与が推測され た.

\section{文献}

1）斉藤 明, 小川洋史, 高木豊巳, 鄭 大基 : Protein -permeable hemofilter による大分子量物質の除去 と臨床効果. 腎と透析 $15: 767-772,1983$

2）小林 肇, 小笠原雅幸, 長谷川豊, 老久保和雄, 大 庭志摩子, 野呂文江, 千葉栄市, 菅原剛太郎 : Protein -permeable hemodialysis の臨床評価. 腎と透析 別冊: 56-61, 1986

3) Saito A, Ogawa H, Chung TG, Maeda K : CAPD and Protein-permeating hemodialysis : A clinical comparison. In "Frontiers in Peritoneal Dialysis" ed Maher JF \& Winchester JF, p 307-311, Field, Rich and Associates Inc, New York, 1986

4）樋口順三, 小沢喜久夫, 酒井清孝 : EVAL-C 膜 11 か 月間連続使用の臨床評価. 腎と透析, 別冊：172-174, 1987

5）鈴木正司, 高橋幸雄, 平沢由平 : 透析アミロイド症 の対策と現況，腎と透析 別冊，32-38，1987

6) 小早川裕之, 新里高弘, 高井一郎, 藤田芳郎, 前田 憲志：関節痛を訴える長期透析患者の push/pull HDF あるいは HD による治療. 腎と透析 別冊 : 133-138， 1988

7）穴戸寬治, 高山公洋, 児島弘臣, 衣笠えり子, 中山 文義, 高橋 健, 秋沢忠夫, 佐藤昌志, 北岡建樹, 出浦照国, 越川昭三: タンパク透過性血液濾過透析 の臨床効果. 人工藏器 $15: 1202-1204,1986$

8) 千葉栄市：血液浄化法の選択. 臨床透析 $4: 71-75$, 1988

9) Radtke HW, Rege AB, La Marche MB, Bartos D, Bartos F, Campbell RA, Fisher JW : Identification of spermine as an inhibitor of erythropoiesis in patients with chronic renal failure. J Clin Invest
$67: 1623-1629,1981$

10) Freedman $M H$, Saunders EF, Cattran DC, Rabjn $\mathrm{E}$ : Ribonuclease inhibition of erythropoiesis in anemia of uremia. Am J Kidney Dis $2: 530-533$, 1983

11）高橋 健, 中島 豊, 平良隆保, 児島弘臣, 田村克 彦, 衣笠えり子, 森河 浄, 関口 孝, 中山文義, 秋沢忠男, 佐藤昌志, 北岡建樹, 出浦照国, 越川昭 三，小出桂三：経口吸着療法活用性炭の腎性貧血へ の効果, 第 28 回人工透析研究会抄録集, 212,1983

12) Lacour B, Basile $C$, Drucke $T$ : Hyperparathyroidism and red cell production. Kidney Int 18 : 137, 1980

13) McGonigle RJ, Parsons V : Aluminum induced anemia in haemodialysis patients. Nephron $39: 1$ $-9,1985$

14）斉藤 明, 小川洋史, 高井一郎, 小野正孝, 高木豊 巳：慢性腎不全血中の中分子量造血抑制因子の High-Performance filter による除去. 腎と透析 別冊 107-112, 1986

15) Freedman MH, Cattran DC, Saunders EF : Anemia of chronic renal failure : Inhibition of erythropoiesis by uremic serum. Nephron $35: 15-19$, 1983

16) McGonigle RJ, Boineau FG, Beckman B, Ohene -Frempong K, Lewy JE, Shadduck RK, Fisher JW : Erythropoietin and inhibitors of in vitro erythropoiesis in the development of anemia in children with renal disease. J Lab Clin Med 105 : 449-458, 1985

17) Meredith PA, Elliott HL, Campbell BC, Moore MR : Changes in serum aluminum, blood zinc, blood lead and erythrocyte delta aminolevulinic acid dehydrogenase activity during haemodialysis. Toxicology $4: 419-424,1979$

18) Huber CT, Frieden $\mathrm{E}:$ The inhibition of ferroxidase by trivalent and other metal ions. $\mathrm{J}$ Biol Chem $245:$ 3979-3984, 1970

19) Touam M, Martinez F, Lacour B, Bourdon R, Zingraff J, Digiulio S, Drueke $\mathrm{T}$ : Aluminum induced, reversible microcytic anemia in chronic renal failure : Clinical and experimental studies. Clin Nephrol $19: 295-298,1983$

20) Gejyo F, Yamada T, Odani S, Nakagawa $Y$, Arakawa M, Kunitomo T, Kataoka H, Suzuki M, Hirasawa Y, Shirahama T, Cohen AS, Schmid 
$\mathrm{K}:$ A new form of amyloid protein associated with chronic hemodialysis was identified as $\beta_{2}$ -microglobulin. Biochem Biophys Res Commun $129: 701-706,1985$

21）関口 高, 金森直明, 穴戸寬治, 高山公洋, 中島 豊, 衣笠えり子, 中山文義, 高橋 健, 秋沢忠男, 北岡 建樹, 越川昭三：難治性腎性貧血の成因と DFO 投 与の有効性について。日腎誌 $29: 918,1987$

22) Meytes D, Bogin E, Ma A, Dukes PP, Massry $\mathrm{SG}$ : Effect of parathyroid hormone on eryth- ropoiesis. J Clin Invest 67 : 1263-1269, 1981

23) Bogin E, Massry SG, Levi J, Djaldeti M, Bristol G, Smith J : Effect of parathyroid hormone on osmotic fragility of human erythrocytes. J Clin Invest $69: 1017-1025,1982$

24) Winearls CG, Oliver DO, Pippard MJ, Reid C, Downing MR, Cotes PM : Effect of human erythropoietin derived from recombinant DNA on the anemia of patients maintained by chronic haemodialysis. Lancet ii : 1175-1177, 1986 